\title{
Perkembangan Museum Kerinci (Tinjauan Historis)
}

\author{
Arki Aulia Hadi, Jamal Mirdad \\ Institut Agama Islam Negeri Bukittinggi \\ Institut Agama Islam Negeri Kerinci \\ arkilpm@gmail.com
}

\begin{abstract}
This paper aims to explain the history and development of the Kerinci Museum. Kerinci Museum is one of the museums on the prop. Jambi and is a state museum which is located outside the capital city of Jambi province, precisely in Kab. Kerinci. The research method in this paper uses historical research methods, namely heuristics (source collection), source criticism, synthesis (data analysis), historiography (writing). The results showed that the Kerinci Museum was built to maintain the values and culture of the Kerinci community, both in the form of Cultural Heritage Objects (BCB) as well as customs and traditions. The early Kerinci Museum was founded and experienced obstacles, such as conflicts over land which still belonged to residents and the construction site. The Kerinci Museum construction process went through three stages. After being founded, this museum experienced another problem, namely the very minimal collection. Until this research was completed, the Kerinci Museum was still looking for objects suspected of being cultural heritage to be used as collections.
\end{abstract}

\section{Keywords: Kerinci, Museum, History}

Abstrak. Tulisan ini bertujuan untuk menjelaskan bagaimana sejarah dan perkembangan Museum Kerinci. Museum Kerinci merupakan salah satu museum yang terdapat di prop. Jambi dan merupakan sebuah museum negeri yang lokasinya berada di luar ibu kota provinsi Jambi, tepatnya di Kabupaten. Kerinci. Metode penelitian dalam tulisan ini menggunakan metode penelitian sejarah, yaitu heuristik (pengumpulan sumber), kritik sumber, sintesis (analisis data), historiografi (penulisan). Hasil penelitian menunjukkan bahwa Museum Kerinci dibangun untuk mempertahankan nilai dan budaya masyarakat Kerinci, baik berupa Benda Cagar Budaya (BCB) maupun adat dan tradisi. Museum Kerinci awal didirikan sempat mengalami hambatan, seperti konflik lahan yang masih milik warga dan lokasi pembangunan. Proses pembangunan Museum Kerinci melalui tiga tahapan. Setelah didirikan, museum ini mengalami kendala lain yaitu sangat minim koleksi. Hingga penelitian ini selesai dilaksanakan, Museum Kerinci masih mencari benda yang diduga sebagai cagar budaya untuk dijadikan koleksi.

\section{Kata Kunci: Kerinci, Museum, History}

\section{PENDAHULUAN}

Museum disebut sebagai pengawal warisan budaya. Pengawal warisan budaya mengandung makna bahwa warisan budaya juga ditampilkan oleh 
museum kepada masyarakat. Dalam perkembangannya museum tidak hanya berhubungan dengan masalah benda-benda kuno, benda warisan budaya, tetapi juga meliputi museum yang membahas teknologi, sejarah atau peristiwa-peristiwa serta museum yang menggambarkan tokoh-tokoh penting. Apapun bentuk museum yang pasti fungsi pokoknya terhadap pengunjung adalah berkomunikasi, edukasi dan memberi pelajaran kognitif (Sumadio, 1997; Sutaarga, 1991; Yulfian Azrial, 2018).

Secara etimologi, museum berasal dari bahasa Latin yakni musea yang aslinya berasal dari bahasa Yunani yakni mouseion yang sejarahnya berupa nama kuil yang dipersembahkan untuk Dewa Kesenian Yunani yakni Muses. Menurut Kamus Besar Bahasa Indonesia (KBBI), museum adalah gedung yang digunakan sebagai tempat untuk pameran tetap benda-benda yang patut mendapat perhatian umum, seperti peninggalan sejarah, seni dan ilmu, serta tempat penyimpanan barang-barang kuno (Kamus Besar Bahasa Indonesia (KBBI) Daring, 2019).

Sudah menjadi sifat alami manusia untuk berfikir, menciptakan dan mengumpulkan barang-barang semasa hidupnya, bahkan barang-barang tersebut bisa tersimpan dan terwariskan kepada keturunannya walau sang pemilik aslinya telah meninggal dunia. Kegemaran ini juga sudah dilakukan oleh bangsa Yunani Kuno yang gemar menaruhkan koleksi barang mereka ke dalam suatu kuil yang dipersembahkan untuk Dewa Seni mereka yakni Muses. Bangsa Eropa Kuno terutama Romawi Kuno dan Yunani Kuno juga gemar menaruhkan harta-harta rampasan perang mereka melawan bangsa lain ke dalam kuil-kuil keagamaan mereka. Bangsa Sumeria juga melakukan hal yang sama sekitar abad ke-6 SM dan bangsa Mesopotamia pada abad ke-2 SM, mereka semua menaruh barang-barang antik, kuno dan karya seni mereka ke dalam kuil-kuil (R.Tjahjoputnomo, 2011: 3).

Pengelolaan museum mereka jauh lebih baik lagi dengan masuknya era renaissance atau era kebangkitan kembali pada abad ke-15 M. Bangsa Eropa 
juga mengembangkan museum-museum mereka lewat kegiatan bisnis mereka, sangat mereka pergi berlayar menuju daerah-daerah bahkan benuabenua yang lain, mereka juga membawa pulang barang-barang dari wilayah perdagangan mereka menuju kampung halaman mereka dan memamerkan barang-barang antik tersebut lewat museum-museum mereka hingga berkembang pesat pada abad ke-17 M (R.Tjahjopurnomo, 2011: 3).

Begitu pula di kawasan Kerinci, dengan identitas dan kekayaan budaya yang luar biasa dapat menghasilkan benda-benda cagar budaya ataupun khazanah ilmu pengetahuan berupa naskah-naskah klasik. Sehingga dengan kehadiran museum ini, dapat menampung dan menyelamatkan benda cagar budaya di Kerinci. Eksistensi museum di Kerinci mendapat apresiasi dari kalangan budaya, cendekiawan dan masyarakat Kerinci pada umumnya. Untuk itu, pentingnya melihat perjalanan dan perkembangan museum di Kerinci. Dengan adanya artikel ini, dapat memberikan gambaran jelas eksistensi museum di Kerinci dan perkembangannya serta dapat dijadikan tolak ukur untuk mengevaluasi kebijakan-kebijakan yang dilakukan oleh pihak pengelolaan museum di Kerinci.

Adapun Jenis penelitian yang digunakan dalam penelitian ini yaitu penelitian kualitatif, dalam pelaporannya peneliti melaporkan dengan cara deskriptif analitis. Metode yang digunakan dalam penelitian ini adalah metode penelitian sejarah. Metode penelitian sejarah bertujuan untuk merekonstruksi peristiwa masa lalu secara sistematis dan objektif dengan cara mengumpulkan, mengevaluasi penemuan, memverifikasi serta menganalisa bukti-bukti dari data-data yang didapatkan untuk membuat kesimpulan yang kuat. Adapun tahapan dalam metode penelitian sejarah menurut Dudung Abdurrahman terdiri dari langkah-langkah sebagai berikut:(1) beuristik adalah usaha dan teknis atau cara untuk menemukan, menyelidiki, mengumpulkan sumber-sumber sejarah atau penelitian. Heuristik dilakukan dengan cara melakukan wawancara dan mencari arsip-arsip terkait dengan penelitian yang 
terkait.(2) Kritik sumber, pada tahap ini sumber-sumber yang telah dikumpulkan pada kegiatan heuristik yang berupa, buku-buku yang relevan dengan pembahasan yang terkait, maupun hasil observasi di lapangan. Setelah bukti atau data itu ditemukan maka dilakukan penyaringan atau penyeleksian dengan mengacu pada prosedur yang ada, yakni sumber yang faktual dan orisinalnya terjamin. (3) Sintesis atau analisis data. Setelah melalui tahapan kritik sumber, kemudian dilakukan sintesis atau interpretasi yang merupakan penafsiran terhadap fakta sejarah yang diperoleh dari koleksi museum yang arsip, buku-buku yang relevan dengan pembahasan, maupun hasil penelitian langsung dilapangan dan wawancara dengan narasumber. Tahapan ini menuntut kehati-hatian dan integritas peneliti untuk menghindari interpretasi yang subjektif terhadap fakta yang satu dengan fakta yang lainnya agar ditemukan kesimpulan atau gambaran sejarah yang ilmiah.(4) Historiografi merupakan tahapan akhir dari seluruh rangkaian dari metode historis. Setelah melakukan tahapan heuristik, kritik sumber, serta sintesis, langkah selanjutnya ialah memaparkan hasil penelitian dalam bentuk karya tulis (historiografi). Hasil rangkaian data yang telah dianalisis peneliti tuliskan dalam bentuk artikel ilmiah (Abdurrahman, 1999: 55-67)

\section{HASIL DAN PEMBAHASAN}

\section{Sejarah Permuseuman di Indonesia}

Menurut ICOM (International Council Of Museums) merupakan organisasi internasional yang mewakili museum professional dari 137 negara dan Indonesia merupakan salah satu anggota dari ICOM, museum memiliki beberapa fungsi, antara lain:

a. Mengumpulkan dan pengaman warisan alam dan kebudayaan.

b. Dokumentasi dan penelitian ilmiah.

c. Konservasi dan preservasi.

d. Penyebaran dan pemerataan ilmu untuk umum.

e. Pengenalan dan penghayatan kesenian. 
f. Visualisasi warisan baik hasil alam dan budaya.

g. Cermin pertumbuhan peradaban umat manusia.

h. Pembangkit rasa bertakwa dan bersyukur kepada Tuhan Yang Maha Esa.

Cikal bakal permuseuman Indonesia dimulai sejak ketertarikan bangsa Eropa untuk mencari rempah-rempah ke Indonesia, kekaguman bangsa Eropa dengan kekayaan alam, budaya, flora dan fauna Indonesia yang unik dan antik, rasa keingintahuan mereka yang besar mendorong mereka untuk melakukan pengkajian dan penelitian hingga ke daerah pedalaman Nusantara. Para peneliti diantaranya yakni Georg Eberhard Rumph seorang pegawai VOC asal Jerman yang meneliti dan mengoleksi jenis-jenis tumbuhan dan kerang di Ambon pada 1662 M. Di Batavia, sejumlah orang Eropa mendirikan Bataviaasch Genootschap van Kunsten en Wetenschappen pada 24 April 1778. Berbagai benda arkeologi dan etnografi milik para kolektor dan cendekiawan dikumpulkan di sini, antara lain milik J.C.M. Radermacher (1741-1783) dan Egbert Willem van Orsoy de Flines (1886-1964). Radermacher adalah kolektor numismatik, sementara Orsoy de Flines adalah kolektor keramik. Lembaga ini menjadi cikal bakal Museum Nasional (R.Tjahjopurnomo, 2011: 4).

Pasca kemerdekaan, bangsa Indonesia mulai menaruh perhatian terhadap permuseuman Indonesia. Orang-orang Belanda yang masih aktif bekerja dalam museum-museum yang dibangun Belanda di Indonesia masih diperbolehkan bekerja, pada masa awal kemerdekaan sudah ada dua ahli permuseuman Indonesia yang tak kalah saing dengan kemampuan ahli museum asing, merek adalah Prof. Purbacaraka dan Prof. Husein Jayadiningrat. Pada tahun 1946 pemerintah mulai memfokuskan pengurusan masalah kebudayaan kepada Kementerian Pendidikan Pengajaran dan Kebudayaan sehingga pada tahun 1950 peningkatan pelestarian terhadap peninggalan sejarah dan kebudayan Indonesia telah mulai tumbuh dan berkembang dengan baik (R.Tjahjopurnomo, 2011: 29). 
Bagian Urusan Museum pada tahun 1965 ditingkatkan menjadi Lembaga Museum-Museum Nasional lalu ditingkatkan kembali menjadi Direktorat Museum pada tahun 1968, dan pada tahun 1975 dirubah menjadi Direktorat Permuseuman. Program pembinaan awal dilakukan dengan mulai mendudukkan konsep museum, klasifikasi museum di Indonesia dan memulai program pembangunan museum-museum di Indonesia, yang diprioritaskan setiap ibukota provinsi di Indonesia mempunyai museumnya sendiri sebagai bentuk pameran kekayaan kebudayaan dan sejarah masingmasing daerah (R.Tjahjopurnomo, 2011: 30).

\section{Sekilas Tentang Sejarah Kerinci}

Kabupaten Kerinci merupakan salah satu kabupaten yang ada di Provinsi Jambi. Dalam sejarahnya, tanah Kerinci pada abad ke-14 \& 15 M selalu menjadi rebutan Kerajaan Dharmasraya (Minangkabau) dengan Kerajaan Jambi (Melayu), pada abad ke-16 M Kerinci di bawah kekuasaan dua kerajaan yaitu Kerajaan Inderapura (Minangkabau) dengan Kesultanan Jambi (Melayu), hingga tahun 1904 M Kerinci berhasil dikuasai kolonial Belanda. Saat masa penjajahan Belanda, tanah Kerinci mengalami dua kali masa di bawah kekuasaan daerah yang berbeda-beda. Kerinci masuk ke dalam Karesidenan Jambi (1904-1921), kemudian berganti di bawah Karesidenan Sumatra's Westkust (1921-1942). Pada masa itu, Kerinci dijadikan wilayah setingkat onderafdeeling yang dinamakan Onderafdeeling Kerinci-Indrapura. Setelah kemerdekaan, status administratifnya dijadikan Kabupaten Pesisir Selatan-Kerinci (Wikipedia, 2019). Dari keterangan di atas,dapat disimpulkan bahwa itulah mengapa adat istiadat serta kebudayaan Kerinci sedikit berbeda daripada "saudara" se-Jambi lainnya seperti Bungo, Merangin, Sarolangun, Tebo dan lain sebagainya. Keunikan adat istiadat dan budaya mereka mendapat banyak pengaruh dari Tanah Minangkabau dan Budaya Melayu Jambi. 
Kabupaten Kerinci mempunyai Gunung Kerinci yang tertinggi di Sumatera sehingga diberi julukan "Atap Sumatera”, banyak panorama danau, air terjun, dan beberapa penemuan batu-batu besar peninggalan budaya megalitikum. Selain itu mereka terkenal dengan "sakti-nya" masyarakat mereka. Masyarakat Kerinci adalah segolongan orang-orang yang sangat menjaga adat istiadat dan peninggalan budaya nenek moyang mereka, baik itu untuk kelompok adat maupun yang diturunkan lewat keluarga masingmasing. Mereka masih sangat memegang tradisi adat dan budaya, bahkan kebanyakan masih menyimpan harta pusaka yang umurnya sudah ada sejak masa Raja Pra-Islam Pagaruyung yakni Adityawarman.

\section{Sejarah Berdirinya Museum Kerinci}

Program pembangunan museum provinsi dilaksanakan lewat program Pembangunan Lima Tahun (Pelita) yang kurang lebih memerlukan waktu 30 tahun. Pembangunan museum pertama di Jambi masuk dalam program Pelita II yang dilaksanakan pada tahun anggaran 1974/1975 - 1978/1979, Museum Negeri Provinsi Jambi dibangun melalui dua aspek, yakni aspek fisik berupa pengadaan koleksi serta sarana dan fasilitas. Serta pembangunan nonfisik berupa survei dan penelitian terhadap kekayaan adat, sejarah dan kebudayaan daerah Jambi. Sedangkan dalam program Pelita III - VI akhir tahun 1999, pembangunan Museum Negeri Jambi berupa pembangunan fisik seperti pengadaan tanah, bangunan, sarana dan fasilitas, sumber daya manusia dan pengadaan koleksi. Pembangunan nonfisik lebih difokuskan pada pelatihan sumber daya manusia, survei dan penelitian akan koleksi dan kegiatankegiatan pameran dan penerbitan (R.Tjahjopurnomo, 2011: 30-39). Pasca berlakunya otonomi daerah tahun 1999, kegiatan permuseuman yang sebelumnya dan dikontrol oleh pemerintah pusat dirubah menjadi menjadi sistem desentralisasi, museum-museum provinsi yang sebelumnya dikelola oleh pemerintah pusat kini dikendalikan dan dikelola oleh pemerintah daerah 
masing masing di bawah bagian bidang kebudayaan masing-masing pemerintah provinsi (R.Tjahjopurnomo, 2011: 54).

Pada umumnya masyarakat masih memandang museum sebagai suatu tempat atau lembaga yang bersuasana membosankan, monoton, berpandangan konservatif atau kuno, yang hanya mengurusi berbagai bendabenda kuno kalangan elite untuk kebanggaan dan kekaguman semata, keadaan yang sunyi, dan terkadang agak kurang terurus karena bangunan dan keadaan ruangannya yang terkesan lama dan tidak modern seperti pada saat sekarang. Hal ini dapat mengakibatkan kejenuhan bagi para pengunjung. Namun seharusnya hal ini tidak menjadi suatu halangan bagi masyarakat untuk tidak mengunjungi museum, karena museum juga memperkenalkan proses perkembangan sosial budaya dari suatu lingkungan kepada masyarakat. Masyarakat juga bisa menggunakan museum sebagai wadah untuk tempat rekreasi dan sarana belajar guna menambah pengetahuan khususnya dalam bidang ilmu Sejarah.

Masyarakat Kerinci telah memiliki beberapa peninggalan seni dan budaya, benda -benda tersebut tersimpan hamper di setiap desa dan terekam dalam memori dan hati para masyarakat Kerinci. Pembangunan museum Kerinci ini merupakan bukti kepedulian dan perhatian Pemerintah Pusat terhadap Kebudayaan Suku Kerinci. Museum ini juga merupakan simbol kebanggaan masyarakat suku Kerinci. Tujuan lain dari pembangunan Museum Kerinci sebagai bentuk antisipasi atas kekhawatiran akan musnahnya benda cagar budaya serta adat istiadat kebudayaan Kerinci beserta sejarah-sejarah yang terkandung dalam kehidupan masyarakat dan tanah Kerinci (Buvari, 2019).

Dalam zaman pembangunan teknologi informasi yang cepat berkembang seperti saat ini, peranan museum sangat diharapkan untuk dapat mengumpulkan, merawat, dan mengkomunikasikan berdasarkan hasil observasi dan penelitian dari benda-benda yang merupakan bukti nyata dari 
sejarah masa lampau dan hasil proses pengembangan kebudayaan masyarakat suatu komunitas atau adat untuk kemudian menjadi warisan yang dapat dinikmati oleh masyarakat di masa mendatang. Dalam kasus ini masyarakat Kerinci generasi sekarang dapat memperoleh gambaran tentang suatu kejadian di masa lampau melalui warisan benda-benda sejarah yang ada dalam museum.

Salah satu museum yang harus melakukan fungsinya sebagai pelestari cagar budaya adalah Museum Kerinci. Museum ini merupakan salah satu museum negeri yang ada di provinsi Jambi. Museum ini terletak di kawasan wisata Danau Kerinci, Kecamatan Danau Kerinci, Kabupaten Kerinci, Provinsi Jambi. Museum Kerinci berada di bawah naungan Dinas Pariwisata, Kebudayaan, Pemuda dan Olahraga Kabupaten Kerinci. Oleh karena itu pembangunan Museum Kerinci ini diharapkan bisa memenuhi tujuan-tujuan tersebut.

Pada awalnya, Museum Kerinci bernama Museum Sakti Alam Kerinci. Pemilihan nama Museum Sakti Alam Kerinci juga bukan tanpa alasan dan beberapa pertimbangan. Selain merupakan motto dari masyarakat Kerinci, kata "Sakti Alam" memiliki alasan tersendiri, hal ini dikarenakan Kerinci merupakan salah satu daerah Provinsi Jambi yang memiliki "kesaktian" baik dari segi alam maupun adat dan budaya manusianya. Masyarakat Kerinci yakin bahwa tanah mereka merupakan tanah surga yang dilemparkan ke bumi, hal ini dibuktikan dengan keindahan alamnya yang sangat indah dan berbeda dari alam daerah Provinsi Jambi yang lainnya. Namun pada tahap pembangunan selanjutnya dan ketika diresmikan, nama museum akhirnya menjadi Museum Kerinci.

Peletakan batu pertama pembangunan Museum Kerinci ini sempat mengalami masalah dan kendala, hal ini dikarenakan lokasi pembangunan museum ini mengenai lahan dan rumah warga lokasi pembangunan, bangunan sipil yang terkena proyek pembangunan ini berupa tiga rumah 
warga, satu bangunan TK, kantor kepala desa dan kantor karang taruna, hal ini menyebabkan dua dari empat permenti adat masyarakat Desa Sanggaran Agung marah, untuk mengatasi permasalahan ini keempat permenti dipanggil dan bermusyawarah dengan pihak panitia pembangunan Museum Kerinci dengan hasil panitia pembangunan bersedia mengganti rugi bangunan yang tergusur dengan nominal Rp. 30 Juta sampai Rp. 40 Juta.

Perencanaan pembangunan dan evaluasi Museum Kerinci sudah dilakukan sejak 29-31 Agustus tahun 2015, pada tahun 2015 pembangunan Museum Kerinci memasuki pembangunan tahap kedua dan tahap ketiga yang dipegang tanggung jawabnya oleh PT. EkaPutri, pembangunan tahap ketiga ini berupa tahap pembangunan berupa penambahan atap, plafon, plaster dinding lantai dua luar dan dalam, pemasangan kusen jendela dan pintu dan pekerjaan lain. Pembangunan Museum hingga ke tahap ketiga ini memakan biaya APBN Kementerian Pendidikan dan Kebudayaan sebanyak Rp. 9 Miliar. Pembangunan Museum Kerinci yang memakan anggaran APBN kurang lebih Rp. 15 miliar ini sudah diselesaikan pada tahun 2017 (Kerinci Time, 2016).

Jadwal peresmian dilakukan pada 8 November 2018, peresmian ini langsung dilakukan oleh Menteri Pendidikan dan Kebudayaan RI bersama Gubernur Jambi, Bupati Kabupaten Kerinci dan juga dihadiri Kepala Dinas Kebudayaan Pariwisata Provinsi Jambi dan Kabupaten Kerinci. Namun memasuki pertengahan tahun Oktober 2018 museum ini belum diresmikan dan digunakan oleh Pemerintah Kabupaten Kerinci. Pasalnya anggaran sarana dan prasarana di dalam museum baru bisa dicairkan pada tahun 2018, serta Dinas Pariwisata Kabupaten Kerinci masih melengkapi serta mencari barang-barang koleksi museum nantinya. Namun pembangunan fisik museum sudah mendekati 100 persen.

Peresmian Museum Kerinci yang berlokasi di Kawasan Objek wisata Danau Kerinci ini diselenggarakan serentak dengan acara Hari Ulang Tahun 
Kab. Kerinci yang ke - 60, 8 November Tahun 2018 yang Bertempat di Desa Sanggaran Agung Kec. Danau Kerinci Kab. Kerinci. Acara peresmian sangat meriah, dengan mempertontonkan aksi silat Kerinci, tari Kerinci, dan kuliner masyarakat Kerinci (Jambiupdate.co, 2019).

\section{PENUTUP}

Museum Kerinci merupakan salah satu museum negeri yang baru dan termegah di provinsi Jambi. Museum ini letaknya di luar ibu kota provinsi Jambi, tepatnya di kawasan Wisata Danau Kerinci, Sanggaran Agung, Kab. Kerinci. Museum ini terbuka untuk untuk umum. Museum Kerinci berperan dalam melestarikan peninggalan Benda Cagar Budaya (BCB) yang banyak terdapat pada masyarakat Kerinci. Dengan adanya Museum Kerinci, diharapkan memiliki kontribusi terhadap ilmu pengetahuan bagi masyarakat Kerinci dan masyarakat luas secara umum tentang sejarah dan kebudayaan masyarakat Kerinci. Selain itu, Museum Kerinci menjadi destinasi wisata yang baru bagi para wisatawan yang berkunjung ke Kerinci.

\section{DAFTAR REFERENSI}

Abdurrahman, D. (1999). Metode Penelitian Sejarah. Ciputat: PT Logos Wacana Ilmu.

Buvari, R. T. T. (2019). Museum Kerinci Akan Rawat Budaya Suku Kerinci. Retrieved November 25, 2019, from https://incungalamkerinci.blogspot.com/2016/01/museum-kerinciakan-rawat-budaya-suku.html

Jambiupdate.co. (2019). Pekan Depan, Museum Kerinci Diresmikan.

Retrieved November 25, 2019, from https://jambiupdate.co/artikelpekan-depan-museum-kerinci-diresmikan.html

Kamus Besar Bahasa Indonesia (KBBI) Daring. (2019). Museum.

Kerinci Time. (2016). Tahun 2016 Finishing Pembangunan Museum Sakti Alam Kerinci. Retrieved November 25, 2019, from https://kerincitime.co.id/tahun-2016-finising-pembangunan-museumsakti-alam-kerinci.html

R.Tjahjopurnomo. (2011). Sejarah Permuseuman di Indonesia. Jakarta: Direktorat Permuseuman dan Direktorat Jenderal Sejarah dan Purbakala 
Kementerian Pariwisata dan Ekonomi Kreatif.

Sumadio, B. (1997). Bunga Rampai Permuseuman. Jakarta: Departemen

Pendidikan dan Kebudayaan Direktorat Jenderal Kebudayaan

Direktorat Permuseuman.

Sutaarga, M. A. (1991). Studi Museologia. Jakarta: Direktorat Jenderal

Kebudayaan, Departemen Pendidikan dan Kebudayaan.

Wikipedia. (2019). Kabupaten Kerinci. Retrieved November 25, 2019, from https://id.wikipedia.org/wiki/ Kabupaten_Kerinci.

Yulfian Azrial, N. A. (2018). Pengantar Museologi. Jakarta: Pena Indonesia. 